\title{
PENGARUH PENGGUNAAN HANDPHONE TERHADAP PRESTASI BELAJAR MAHASISWA SEKOLAH TINGGI FILSAFAT JAFFRAY MAKASSAR
}

\author{
Octavianus, Ivan Th. J. Weismann
}

\begin{abstract}
Abstrak
Adapun tujuan penulisan karya ilmiah ini adalah: Untuk mengetahui pengaruh penggunaan handphone terhadap prestasi belajar mahasiswa Sekolah Tinggi Filsafat Jaffray Makassar. Metode penelitian yang digunakan adalah metode kuantitatif. Dan untuk melakukan metode tersebut maka penulis terlebih dahulu melakukan: Pertama, pengambilan dan pengumpulan data melalui jurnal dan buku-buku berkaitan dengan judul yang dibahas dalam skripsi. Kedua, dengan menyebarkan angket kepada mahasiswa Sekolah Tinggi Filsafat Jaffray Makassar. Ketiga, dengan melakukan wawancara langsung kepada pengguna handphone sebagai penguat data. Dari hasil pembahasaan penulis menarik kesimpulan sebagai berikut: pengaruh handphone, sebanyak $87 \%$ responden menggunakan handphone sebagai tempat menghilangkan kejenuhan. Ada $42 \%$ dari responden mengakses facebook/whatsapp lebih lama dari pada waktu belajar. Ada $89 \%$ responden yang menjadikan youtube sebagai media belajar. Ada $89 \%$ responden yang sering memanfaatkan google untuk mendukung dalam Pendidikan. Prestasi belajar, seluruh responden merupakan pengguna handphone, dan nilai rata-rata IP minimal C. Secara eksternal, rata-rata $89 \%$ responden dapat beradaptasi dengan lingkungan. Ada $98 \%$ responden setuju bahwa telah mengalami perubahan kognitif dari apa yang telah dipelajari. Dari $98 \%$ ada $88 \%$ responden menunjukan peningkatan prestasi. Berdasarkan teori konstruktivisme, rata-rata semua responden menjadikan pengalaman sebagai tempat belajar. Dari semua responden $81 \%$ yang mengalami peningkatan nilai IP. Ada pengaruh penggunaan handphone terhadap prestasi belajar mahasiswa dengan hasil korelasi 0.688 berartinya handphone memberi pengaruh sebesar $47 \%$.
\end{abstract}

Kata-kata Kunci: Handphone, Pengaruh, Prestasi, Mahasiswa.

\section{Pendahuluan}

\section{Latar Belakang Masalah}

Pada masa sekarang ini dapat dilihat dan dirasakan bahwa perkembangan teknologi sangat berpengaruh terhadap kehidupan masyarakat. Banyak produk-produk teknologi yang diciptakan guna membantu dan meningkatkan hasil kerja, misalnya adanya laptop/komputer memberi kemudahan dalam pengetikan kemudian mengatur dan mengirim data-data. Mesin bajak membantu mempermudah petani dalam menyediakan lahan siap tanam, pesawat udara sebagai transportasi udara yang lebih menghemat waktu perjalanan, jaringan internet sebagai media untuk dapat berkomunikasi dan berinteraksi dengan orang di berbagai daerah dan masih banyak lagi.

Masa kini kemudahan sudah menjadi bagian dari kehidupan, masyarakat di era perkembangan ini menginginkan hal-hal yang serba instan. Salah satu bagian dari 
kemudahan yang diciptakan untuk memanjakan masyarakat pada umumnya yaitu bidang teknologi informasi dan komunikasi. Dengan adanya kemajuan teknologi informasi dan komunikasi, seseorang dapat menerima dan memberi informasi kepada orang lain di berbagai tempat, dan berinteraksi dengan jutaan orang di berbagai belahan dunia atau dikenal dengan dunia maya. Melalui dunia maya seseorang bisa berkenalan dengan orang lain, dengan alasan untuk mencari teman, melakukan hubungan bisnis, bertransaksi dan dapat juga untuk menawarkan barang dan jasa.

Salah satu teknologi informasi dan komunikasi yang berkembang dan diminati pada saat ini adalah handphone. Menurut Dimitri Mahayana (dosen Sekolah Teknik Elektro dan Informatika ITB yang juga dalam hal data Scientist Sharing Vision), mengenai jumlah pengguna seluler di Indonesia, diprediksi meningkat menjadi 265,3 juta di tahun 2019, dan pengguna smartphone diperkirakan 140,4 juta di tahun 2019, sementara untuk pengguna mobile internet diprediksi menjadi 89,4 juta tahun $2019 .^{1}$

Handphone dirancang dengan ukuran yang kecil sehingga mudah dibawa, tapi memiliki kemampuan hampir sama dengan komputer, ini yang menjadikan handphone lebih diminati. Kemudian ditunjang juga dengan harga handphone yang lebih murah, sehinga terjangkau oleh setiap lapisan masyarakat, dan cara penggunaannya pun cukup mudah apa lagi untuk generasi sekarang ini. ${ }^{2}$ Dalam kegiatan sehari-hari sering ditemui aktivitas orang tua sampai dengan siswa taman kanak-kanak (TK) menggunakan handphone baik untuk mencari informasi maupun sekedar mencari hiburan.

Generasi pada masa kini tumbuh dan berkembangan dengan keadaan masyarakat yang bergantung pada adanya teknologi, sehingga bukan hal yang baru jika mengetahui dalam usia yang sangat belia seseorang sangat terampil dalam menggunakan handphone. ${ }^{3}$ Sebagai sebuah negara yang berkembang, di era pasar global ini berbagai jenis barang elektronik ditawarkan sebagai pemenuh kebutuhan, ini tentunya memiliki dampak positif maupun negatif. Pergerakan perkembangan teknologi ini tidak dapat dibendung atau dihindari dalam kehidupan, karena teknologi sudah menjadi bagian dalam kehidupan masyarakat. Mengenai pengguna handphone, masyarakat yang tinggal di daerah perkotaan tentunya merupakan pengguna aktif handphone. Kemana anda pergi anda pasti berjumpa pengguna handphone, baik di tempat bekerja, sekolah, ibu rumah tangga dan bahkan mereka yang pengganguran, karena handphone merupakan gaya hidup masa kini. ${ }^{4}$ Sebagai salah satu kampus yang berada di tengah kota Makassar, pastinya mahasiswa Sekolah Tinggi Filsafat Jaffray Makassar terhitung sebagai pengguna aktif handphone.

Seorang mahasiswa sempat berdiskusi dan mengatakan bahwa keinginan membuka handphone untuk melihat sosial media sangat kuat dari pada keinginan membuka buku. Sebagai mahasiswa sekolah teologi seharusnya dapat menggunakan waktu dengan baik. Rasul Paulus selalu mengingatkan untuk memperhatikan bagaimana harus hidup sebagai seorang hamba Tuhan. Meski pada masa sekarang tidak ada penganiayaan, namun perkembangan teknologi tidak mendukung dalam penggunaan waktu secara bijaksana (Efesus 5:15-17). Jadi penulis memiliki asumsi bahwa terdapat ketergantungan antara

\footnotetext{
${ }^{1}$ Kamel Setia Pernama, "Ketika Pengguna Internet dan Smartphone Terus Meningkat, Android Dominasi Pasar Indonesia dan Dunia," diakses 3 April 2019, http://jabar.tribunnews.com/2019/01/24/ketikapengguna-internet-dan-smartphone-terus-meningkat-android-dominasi-pasar-indonesia-dan-dunia.

${ }^{2}$ Arum Faiza, Sabila J. Firda, Arus Metamorfosa Milenial (Kendal: Penerbit Ernest, 2019), 29.

${ }^{3}$ Hellen Chou Pratama, Cyber Smart Pranting (Bandung: Visi Anugerah Indonesia, 2012), 35.

${ }^{4}$ Alufi Eka Ukisnawati, "Demam Gadget (Smartphone) Dalam Visualisasi Jati Diri Mahasiswa," (Skripsi S.Ant, Universitas Gadjah Mada, 2014), 105.

http://etd.repository.ugm.ac.id/index.php?mod=penelitian_detail\&sub=PenelitianDetail\&act=view\&typ=html \&buku_id=71973.
} 
mahasiswa dan handphone. Dari pembicaraan itu penulis tertarik ingin mewawancarai beberapa mahasiswa lainnya.

Ada tiga mahasiswa yang sempat penulis wawancarai. Dari tiga mahasiswa yang sempat penulis wawancarai, salah satuya mangatakan jika dalam kegiatan kuliah selama 2 jam tidak diperkenankan mengaktifkan handphone maka mahasiswa merasa stres jika hanya duduk mendengar. ${ }^{5}$ Seorang mahasiswa lagi mengatakan bahwa mahasiswa tersebut menggunakan handphone dalam sehari rata-rata lebih dari 5 jam. ${ }^{6}$ Kedua hasil wawancara di atas sejalan dengan jurnal Resti dengan judul Penggunaan Smartphone Di Kalangan Mahasiswa Fakultas Ilmu Sosial Dan Ilmu Politik Universitas Riau, mengatakan bahwa sebagian besar dari respondennya rata-rata setiap hari menggunakan handphone lebih dari 5 jam, sedangkan jumlah responden yang mau menyisihkan waktunya untuk belajar hanya sedikit. ${ }^{7}$ Dengan penggunaan handphone lebih dari 5 jam sudah termasuk menyita waktu yang banyak dan pastinya ini memiliki pengaruh bagi mahasiswa itu sendiri.

Mahasiswa yang lain mengatakan bahwa mahasiswa tersebut tidak pernah lepas dari menggunakan handphone, kemanapun mahasiswa itu pergi dan di mana ia berada, ia tidak pernah lepas dari handphone kecuali saat tidur. ${ }^{8}$ Hal ini juga yang dituliskan Dedy Susanto dalam jurnalnya yang berjudul "Pengguna Smartphone Dan Locus Of Control: Keterkaitannya Dengan Prestasi Belajar, Kualitas Tidur, Dan Subjective Well-Being," menuliskan bahwa penggunaan handphone sehari-hari, mempengaruhi waktu penggunaan handphone pada saat yang tidak tepat, juga mempengaruhi kualitas tidur mahasiswa dan akhirnya memberi pengaruh terhadap prestasi mahasiswa tersebut. ${ }^{9}$ Hal yang demikian memang sering penulis temukan, biasanya saat kuliah sedang berlangsung ada mahasiswa yang sibuk bermain games, bersosial media, menonton video. Bukan hanya itu bahkan saat ibadah, saat berkumpul dengan teman, biasanya sibuk dengan handphone masing-masing.

Sedangkan Derry Iswidharmanjaya dan Beranda Agency dalam bukunya mengatakan beberapa dampak penggunaan Gadget (handphone) dapat membuat pengguna menjadi pribadi tertutup, karena tentunya tidak senang diganggu saat memainkan handphone-nya. Kemudian penggunaan dalam waktu yang lama dapat mengakibatkan kesehatan mata terganggu, penggunaan handphone berlebihan membuat waktu tidur tidak teratur dan pudarnya kreativitas (copy paste) pengguna jadi malas untuk melakukan hal baru. ${ }^{10}$ Dari beberapa pendapat di atas menunjukkan bahwa penggunaan handphone memiliki dampak yang negatif, baik untuk kesehatan dan untuk hubungan sosial (secara langsung).

Namun dari pengamatan penulis penggunaan handphone dikalangan mahasiswa Sekolah Tinggi Filsafat Jaffray Makassar, selain karena pentingnya akan komunikasi informasi, juga merupakan tempat mencari sumber-sumber belajar baik buku, jurnal, video, film, youtube, belanja online, memesan transportasi secara online (Grab, gojek). Dengan handphone mahasiswa dapat juga berbagi pengalaman melalui media sosial, melihat tren terbaru, meng-upload status dan main games sebagai hiburan. Intan Trivena

\footnotetext{
${ }^{5}$ YM (inisial), Wawancara oleh Penulis, Makassar, Sulawesi Selatan, 9 Maret 2019.

${ }^{6} \mathrm{JH}$ (inisial), Wawancara oleh Penulis, Makassar, Sulawesi Selatan, 9 Maret 2019.

${ }^{7}$ Resti, "Penggunaan Smartphone Di Kalangan Mahasiswa Fakultas Ilmu Sosial Dan Ilmu Politik Universitas Riau," Jurnal Online Mahasiswa Fakultas Ilmu Sosial dan Ilmu Politik Universitas Riau 2, No. 1 (2015): 13. https://jom.unri.ac.id/index.php/JOMFSIP/article/view/4840/4722

${ }^{8}$ AP (inisial), Wawancara oleh Penulis, Makassar, Sulawesi Selatan, 9 Maret 2019.

${ }^{9}$ Dedy Susanto, "Penggunaan Smartphone Dan Locus of Control: Keterkaitannya Dengan Prestasi Belajar, Kualitas Tidur, Dan Subjective Well-Being,” Jurnal Psikologi Sosial 16, No. 2 (2018): 135-136. http://journal.ui.ac.id/index.php/jps/article/view/jps.2018.12

${ }^{10}$ Derry Iswidharmanjaya dan Beranda Agency, Bila Si Kecil Bermain Gadget (Jakarta: EGC, 2014), 15.
} 
mengatakan dalam jurnalnya bahwa handphone pintar juga menunjang aktivitas perkuliahan mahasiswa Fispol Unsrat Manado: (a) Membuat grup kelas dimedia sosial untuk berbagi informasi mengenai aktivitas perkuliahan, (b) Mencari arti lewat google atau aplikasi yang berkaitan mengenai arti kata atau materi yang sedang dibahas, (c) Mendownload buku-buku atau artikel-artikel ilmiah, (d) Membuka Portal Akademik untuk mengisi KRS, mengecek KHS dan trenskrip nilai, (e) Melakukan KKT secara online. ${ }^{11}$

Dalam lingkungan kampus STT Jaffray sendiri, terdapat beberapa matakuliah yang memiliki hubungan dengan penggunakan media, yaitu matakuliah Teologi dan Teknologi Informasi, yang membahas mengenai penggunaan sosial media, blog, vlog dan website untuk tujuan pelayanan dan penginjilan. Selanjutnya mengetahui dan mempelajari beberapa website dan software untuk belajar Alkitab, teknik pelayanan dan penginjilan. Kemudian dari wawancara dengan D (inisial) mengatakan untuk matakuliah gitar dasar, gitar klasik, dan piano adanya youtube dan google sangat membantu. ${ }^{12}$

Hasil wawancara penulis dengan beberapa mahasiswa, mahasiswa pertama, penggunaan media berhubungan dengan belajar, ia lebih sering menggunakan google dalam mendukung proses belajar, untuk mencari jurnal, berita, video dan informasi lainnya. Kemudian whatsapp sebagai sarana berbagi informasi perkuliahan, waktu pengumpulan tugas dan kapan waktu ujian. Kemudian facebook digunakan untuk membagikan ayat Alkitab dan kalimat motivasi. Sedangkan youtube jarang digunakan, karena yang bersangkutan mengatakan mudah terpengaruh untuk membuka video lain yang tidak berhubungan dengan pelajaran. ${ }^{13}$

Mahasiswa kedua menggatakan, ia lebih banyak menggunakan youtube untuk mencari hiburan dibandingkan hal yang berhubungan dengan pelajaran. Sedangkan facebook dan whatsapp digunakan untuk berbagi informasi dengan teman, mengenai tugas dan mengenai waktu ujian. Kemudian google jarang untuk digunakan, terkecuali ada tugas yang diberikan dosen. ${ }^{14}$

Mahasiswa ketiga mengatakan bahwa ia sering menggunakan youtube sebagai hiburan dan juga sebagai tempat belajar terutama pada mata kuliah piano. Sedangkan facebook dan whatsapp biasanya dalam grup hanya untuk melihat informasi dari teman. Kemudian mengenai penggunaan google sangat jarang terkecuali saat ada tugas mencari jurnal dari dosen. Dari hasil wawancara diatas penulis menyimpulkan bahwa penggunaan handphone memberi manfaat bagi mahasiswa meski tidak maksimal.

Penggunaan handphone sudah menjadi gaya hidup mahasiswa masa kini yang menjurus kepada kebutuhan. Dan pengaruh penggunaan handphone dalam kehidupan seseorang dari satu segi membawa dampak baik, tetapi dari segi lain membawa dampak yang buruk bagi penggunanya. Pada penulisan ini penulis bertujuan untuk meneliti mengenai penggunaan handphone yang terdiri dari media sosial dan internet sebagai media belajar untuk meningkatkan prestasi belajar mahasiswa Sekolah Tinggi Filsafat Jaffray Makasaar, dan membatasi media yang digunakan yaitu Facebook, WhatsApp, YouTube dan Google.

Mengacu kepada uraian di atas, maka penulis tertarik untuk menuangkan masalah tentang bagaimana kehadiran handphone dapat memberikan pengaruh kepada pengguna secara efektif. Dengan demikian penulis mengangkat sebuah masalah dalam karya ilmiah

\footnotetext{
${ }^{11}$ Intan Trivena Maria Daeng N.N Mewengkang Edmon R Kalesaran, "Penggunaan Smartphone Dalam Menunjang Aktivitas Perkuliahan Oleh Mahasiswa Fispol Unsrat Manado," Jurnal ACTA DIURNA 8 (2017): 14, https://ejournal.unsrat.ac.id/index.php/actadiurna/article/view/15482/15023.

${ }^{12}$ D (inisial), Wawancara oleh Penulis, Makassar Sabtu 10 Agustus 2019.

${ }^{13}$ IKA (inisial), Wawancara oleh Penulis, Makassar, Sulawesi Selatan, 4 Agustus 2019.

${ }^{14} \mathrm{~K}$ (inisial), Wawancara oleh Penulis, Makassar, Sulawesi Selatan, 5 Agustus 2019.
} 
dengan judul: PENGARUH PENGGUNAAN HANDPHONE TERHADAP PRESTASI BELAJAR MAHASISWA SEKOLAH TINGGI FILSAFAT JAFFRAY MAKASSAR.

\section{Pokok Masalah}

Berdasarkan pembahasan diatas, maka yang menjadi pokok masalah adalah:

Bagaimana pengaruh penggunaan handphone terhadap prestasi belajar mahasiswa Sekolah Tinggi Filsafat Jaffray Makassar.

\section{Tujuan Penelitian}

Adapun tujuan yang ingin dicapai melalui penulisan skripsi ini adalah: untuk mengetahui bagaimana pengaruh penggunaan handphone terhadap peningkatan prestasi mahasiswa.

\section{Manfaat Penelitian}

Pertama, tulisan karya ilmiah ini dapat menjadi bahan bacaan yang dapat memberi wawasan bagi para pembaca.

Kedua, sebagai bahan masukan bagi mahasiswa dan Sekolah terhadap pengaruh handphone terhadap prestasi mahasiswa.

Ketiga, sebagai salah satu persyaratan akademik dalam penyelesaian studi di Sekolah Tinggi Filsafat Jaffray Makassar.

\section{Metode Penelitian}

Metode penelitian yang digunakan dalam penulisan skripsi ini adalah dengan menggunakan metode kuantitatif dan untuk melakukan metode penelitian ini, ${ }^{15}$ hal yang akan dilakukan adalah:

Pertama, mengambil dan mengumpulkan data melalui buku, jurnal dan artikel yang berkaitan dengan judul.

Kedua, dengan melakukan penyebaran angket kepada mahasiswa Sekolah Tinggi Filsafat Jaffray Makassar.

Ketiga, dengan melakukan wawancara langsung kapada pengguna aktif handphone sebagai penguat data.

\section{Batasan Penelitian}

Pada batasan penelitian ini penulis membatasi penulisan ini pada pengaruh penggunaan handphone terhadap prestasi belajar mahasiswa Sekolah Tinggi Filsafat Jaffray.

\footnotetext{
${ }^{15}$ Hasmawaty, 55; Sareong dan Supartini, 29; Serli dan Wijaya, 17.
} 


\section{Sistematika Penulisan}

Agar mudah memahami penulisan skripsi ini, maka penulis menyusunnya dengan sistem sebagai berikut:

Bab pertama, merupakan pendahuluan yang terdiri dari latar belakang masalah, pokok masalah, tujuan penelitian, manfaat penelitian, metode penelitian, Batasan penelitian dan sistematika penelitian.

$\mathrm{Bab}$ dua, merupakan tinjauan pustaka yang menjelaskan beberapa pokok dalam pembahasan sehubungan dengan topik penulisan Karya ilmiah. Bagian yang pertama, membahas mengenai handphone; definisi, sejarah handphone, data pengguna handphone yang terdiri dari data pengguna handphone secara global di Indonesia, media pembelajaran dan handphone dalam pembelajaran. Bagian kedua, membahas mengenai prestasi; pengertian prestasi dan faktor-faktor yang mempengeruhi prestasi baik internal maupun eksternal. Selanjutnya teori prestasi belajar antaralain teori konstruktivisme dan teori kognitivisme. Bagian ketiga, penelitian yang relevan tentang hubungan handphone terhadap prestasi diantaranya; Pengaruh Penggunaan Smartphone Terhadap Prestasi Belajar Mahasiswa Melalui Motivasi Belajar, Pengaruh Smartphone Terhadap Prestasi Balajar Siswa Kelas 8 MTs. Wali Songo Sugihwaras Bojonegoro, Pengaruh Penggunaan Smartphone Terhadap Nilai Akademik Mahasiswa, Smartphone Sebagai Media Pembelajaran "Student Centered Learning."

Bab tiga, pada bab ini yang akan dibahas ialah mengenai gambaran umum tentang lokasi penelitian yang terdiri dari fasilitas, letak geografis, visi dan misi Sekolah Tinggi Filsafat Jaffray Makassar. Kemudian membahas mengenai jenis penelitian yang akan digunakan yaitu penelitian kuantitatif, populasi, sampel. Kemudian selanjutnya akan membahas mengenai teknik pengumpulan data yang terdiri dari kajian pustaka, angket dan wawancara dan dilanjutkan dengan teknik analisi data.

Bab empat, membahas mengenai analisis hasil data penelitian dan pembahasannya yang terdiri dari subjek penelitian, analisis hasil penelitian dan kesimpulan analisis data.

Bab lima, merupakan penutup yang mana hanya merupakan pembahasan kesimpulan dan saran-saran.

\section{Kesimpulan}

Pada akhir dari penulisan skripsi ini, maka penulis memberi kesimpulan sebagai berikut:

Pertama, hasil dari angket penggaruh penggunaan handphone menunjukan lebih dari $87 \%$ mahasiswa menggunakan handphone pada aplikasi whatsapp dan facebook, untuk berbagi informasi dan materi. Youtube sebagai tempat belajar dan mencari pengetahuan baru dan google untuk menemukan berita, jurnal, artikel dan buku.

Kedua, hasil dari angket prestasi belajar, menunjukan seluruh mahasiswa menggunakan handphone, tetapi nilai indeks prestasi minimal C. Dengan hasil; faktor internal 100\%, faktor eksternal 92\%, kognitivisme 98\%, konstruktivisme $100 \%$.

Ketiga, dari hasil tabel korelasi antara pengaruh penggunaan handphone terhadap prestasi belajar, pada tabel interprestasi koefisien menunjukan tinggkat hubungan yang kuat dengan hasil $\mathrm{r}=0.688(47 \%)$. 


\section{Saran-saran}

Pada akhir dari skripsi ini penulis memberikan saran sebagai masukan berhubungan dengan pengaruh penggunaan handphone terhadap prestasi belajar mahasiswa Sekolah Tinggi Filsafat Jaffray Makassar.

Pertama, penulis mengharapkan disaat sekarang ini dimana lebih banyak orang menggunakan handphone secara berlebihan, sebagai mahasiswa teologi sebaiknya selalu menggunakan apa yang ada dengan bijak sehingga tidak terpengaruh oleh keadaan melainkan mempengaruhi.

Kedua, penulis mengharapkan dengan adanya kecangihan handphone pada saat ini dapat dimanfaatkan sehingga mempengaruhi prestasi belajar setiap mahasiswa menjadi lebih baik, untuk kemuliaan Tuhan.

Ketiga, kiranya dengan adanya penulisan ini dapat menjadi salah satu pedoman yang bermanfaat dalam penggunaan handphone untuk meningkatkan prestasi belajar mahasiswa STT Jaffray Makassar.

\section{Kepustakaan}

Ali, Mohamad. Penelitian Kependidikan. Bandung: Bumi Angkasa, 1981.

Amin, Mukhamat Fatkhur. "Pengaruh Smartphone Terhadap Prestasi Belajar Siswa Kelas 8 MTs. Wali Songo Sugihwaras Bojonegoro.” Skripsi, Sarjana Pendidikan Agama Islam Surabaya, 2018. http://digilib.uinsby.ac.id/27216/\#.

Augusta, Gardenia. "Pengaruh Penggunaan Smartphone Terhadap Prestasi Belajar Mahasiswa Malaui Motivasi Belajar." Skripsi, S.Pd, Universitas Sanata Dharma Yogyakarta, 2018. https://repository.usd.ac.id/17687/.

Badaruddin, Achmad. Peningkatan Motivasi Belajar Siswa Melalui Konseling Klasikal. Padang: Abe Kreatifindo, 2015.

Barus, Ulian dan Suratno, Manfaat Candi Bahal Sebagai Media Pembelajaran Alam Terbuka Dalam Proses Belajar Mengajar. Medan: DIPA Wilayah 1, 2015.

Data Profil Sekolah Tinggi Filsafat Jaffray Makassar. Diakses 16 Juni 2019. https://www.sttjaffray.ac.id/profil/mengenal-stt-jaffray.

Darmadi. Pengembangan Model dan Metode Pembelajaran Dalam Dinamika Belajar Siswa. Yogyakarta: Penerbit Deepublish, 2017.

Darmanto, Sri Wardaya, dan Titik Dwiyani, Bauran Orientasi Strategi Dan Kinerja Organisasi Penerapan Variabel Anteseden, Moderasi, Dan Mediasi Dalam Penelitian Ilmiah. Yogyakarta: Penerbit Deepublish, 2015.

Dandim, Sudarwan. Riset Keperawatan: Sejarah dan Metodologi. Jakarta: Penerbit Buku Kedokteran EGC, 2002.

Duludu, Ummyssalam A.T.A. Buku Ajar Kurikulum Bahan Dan Media Pembelajaran PLS. Yogyakarta: Penerbit Deepublish, 2017.

Endra, Febri. Pedoman Metodologi Penelitian. Sidoarjo: Penerbit Zifatama Jawara, 2017.

Fasilitas Kampus Sekolah Tinggi Filsafat Jaffray Makassar. https://www.sttjaffray.ac.id/fasilitas-layanan/fasilitas-kampus.

Faiqah, Fatty. Muhammad Nadjib dan Andi Subhan Amisr. "Youtube Sebagai Sarana Komunikasi Bagi Komunitas Makassarvidgram." Jurnal Ilmu Komunikasi 5, No. 2, (2016): 259-272. http://journal.unhas.ac.id/index.php/kareba/article/view/1905.

Fatmawati, Sri. Nina Ariesta, Laily Yunita Susanti, Darmaji dan Surya Rosa Putra. Desain Labolatorium Skala Mini Untuk Pembelajaran Sains Terpadu. Yogyakarta: Penerbit Deepublish, 2015. 
Firdaus dan Fakhry Zamzam. Aplikasi Metodologi Penelitian. Yogyakarta: Penerbit Deepublish, 2018.

Firda, Sabila J. Arum Faiza. Arus Metamorfosa Milenial. Kendal: Penerbit Ernest, 2019.

Firdianti, Arinda. Implementasi Manajemen Berbasis Sekolah Dalam Meningkatkan Prestasi Belajar. Yogyakarta: Gre Publishing, 2018.

Gondrasi, Aleysius H. Rahasia 5 Eleman Untuk Cerdas dan Sukses Sri Mulyani, Bill Gates dan Steve Jobs. Jakarta: Gramedia Pustaka Utama, 2012.

Hakim, Thursan. Belajar Secara Efektif. Jakarta: Puspa Swara, 2005.

Hamdi, Asep Saepul. Metode Penelitian Kuantitatif Aplikasi Dalam Pendidikan. Yogyakarta: Deepublish, 2014.

Harso dan Ridhi Syukra. 2018, Pengguna Smartohone Capai 100 Juta. Berita Satu, 20 Maret 2019. https://id.beritasatu.com/home/2018-pengguna-smartphone-capai-100juta/176965.

Hasmawaty. "Kemampuan Menyimak Anak Melalui Kegiatan Bercerita (Studi Kasus Pada Taman Penitipan Anak Athirah Makassar)." Jurnal Ilmu Teologi dan Pendidikan Agama Kristen 1, no. 1 (Juni 2020): 55-68.

https://ojs.sttjaffray.ac.id/jitpk/article/view/463/pdf_4.

Iswidharmanjaya, Derry dan Beranda Agency. Bila Si Kecil Bermain Gadget. Jakarta: EGC, 2014.

Juju, Dominikus. Seri Penuntun Praktis Facebook. Jakarta: Elex Media Komputindo, 2013.

Juraman, Stefanus Rodrick. "Manfaat Smartphone Android Oleh Mahasiswa Ilmu Komunikasi Dalam Mengakses Informasi Edukatif," Jurnal Acta Diurna 3 (2014): 14-15. https://ejournal.unsrat.ac.id/index.php/actadiurna/article/view/4493.

Kamus Besar Bahasa Indonesia Edisi Ketiga. Jakarta: Balai Pustaka, 2001.

Klaudia, Jenifer. "Pengaruh Penggunaan Smartphone Terhadap Pertumbuhan Kerohani Mahasiswa-Mahasiswi Di Sekolah Tinggi Theologia Jaffray Makassar." Skripsi, S.Pd, Sekolah Tinggi Filsafat Jaffray, 2017.

Komputer, Wahana. Kupas Tuntas Aplikasi Terbaik dan Populer Google Play. Jakarta: Elex Media Komputindo, 2012.

Komaruudin. Kamus Riset. Bandung: Angkasa, 1984.

Kustiawan, Usep. Pengembangan Media Pembelajaran Anak Usia Dini. Malang: Penerbit Gunung Samudra, 2016.

Kurniawan, Iwan Setia dan Topik Hidayat. "Aplikasi Smartphone Dalam Pembelajaran Biologi," dalam Ketut Wikantika. Bunga Rampai Forum Peneliti Muda Indonesia 2017. Bandung: ITB, 2017.

Mikha Agus Widiyanto. Statistik Untuk Penelitian Bidang Teologi, Pendidikan Agama Kristen \& Pelayanan Gereja: Lengkap dengan konsep dan Aplikasi SPSS. Bandung: Kalam Hidup, 2014.

Munadi, Yudhi. Media Pembelajaran: Sebuah Pendekatan Baru. Jakarta: Gaung Persada, 2008. Diikuti oleh Andi Prastowo, Sumber Belajar \& Pusat Pembelajaran. Depok: Prenadamedia Group, 2018.

Naim, Ngainun. Menjadi Guru Inspiratif Memberdayakan Dan Mengubah Jalan Hidup Siswa. Yogyakarta: Pustaka Pelajar, 2011.

Nazir. Metode Penelitian. Jakarta: Ghalia Indonesia, 1983.

Neolaka, Amos dan Grace Amilia. Landasan Pendidikan Dasar Pengenalan Diri Sendiri Manuju Perubahan Hidup. Depok: Kencana, 2017.

Nizarwati, Yusuf Hartono dan Nyimas Aisyah, "Pengembangan Perangkat Pembelajaran Berorientasi Konstruktivisme Untuk Mengejarkan Konsep Perbandingan 
Trigonometri Siswa Kelas X SMA,” Jurnal Pendidikan Matematika 3, no. 2 (2009): 57-72. http://eprints.unsri.ac.id/823/.

Nuryanto, Hery. Sejarah Perkembangan Teknologi Informasi dan Komunikasi. Jakarta: Balai Pustaka, 2012.

Maria, Naova. "Pengaruh Penggunaan Smartphone Terhadap Nilai Akademik Mahasiswa," 4, No.2 (2013): 652-658.

https://journal.binus.ac.id/index.php/comtech/article/view/2488.

Pernama, Kamel Setia. "Ketika Pengguna Internet dan Smartphone Terus meningkat, Android Dominasi Pasar Indonesia dan Dunia." Bandung: Tribun Jabar.id, 3 April 2019. http://jabar.tribunnews.com/2019/01/24/ketika-pengguna-internet-dansmartphone-terus-meningkat-android-dominasi-pasar-indonesia-dan-dunia.

Sudirdjo, Sudarsono. dan Eveline Siregar, Media Pembelajaran Sebagai Pilihan Dalam Strategi Pembelajaran. Jakarta: Kencana, 2007, Sudarsono Sudirjo dan Eveline Siregas mengutip Dewi Salma Prawiradilaga dan Eveline Siregar. Mozaik Teknologi Pendidikan. Jakarta: Kencana, 2004.

Pratama, Hellen Chou. Cyber Smart Pranting. Bandung: Visi Anugerah Indonesia, 2012.

Putrawangsa, Desain Pembelajaran: Design Research Sebagai Pendekatan Desain Pembelajaran. Mataram: Reka Karya Amerta, 2018.

Purwanto, Endy. "2018: Pengguna Smartphone Indonesia Tembus 103 Juta Orang." Ayoo berita.com. Diakses 07 April 2019. https://www.ayooberita.com/berita-----2018pengguna-smartphone-indonesia-tembus-103-juta-orang.

Pimpinan STF Jaffray Makassar. Diakses 16 Juni 2019. https://www.sttjaffray.ac.id/profil/pimpinan-stt-jaffray-makassar.

R. Wilman dan Riyan. Mengenali dan Mengatasi Kerusakan Software Handphone. Tanggerang: Kawan Pustaka, 2006.

Rahmayani, Indah. "Indonesia Raksasa Teknologi Digital Asia.” Kementrian Komunikasi Dan Informatika Republik Indonesia, 02 Oktober 2019. https://www.kominfo.go.id/ content/ detail/ 6095/indonesia-raksasa-teknologi-digital-asia/0/sorotan_media.

Resti. "Penggunaan Smartphone Di Kalangan Mahasiswa Fakultas Ilmu Sosial Dan Ilmu Politik Universitas Riau, Pekan Baru." Jurnal Online Mahasiswa Fakultas Ilmu Sosial dan Ilmu Politik Universitas Riau 2, No. 1 (2015): 1-15. https://jom.unri.ac.id/index.php/JOMFSIP/article/view/4840/4722.

Riyana, Cepy. Media Pembelajaran. Jakarta: Direktorat Jenderal Pendidikan Islam Kementerian RI, 20112.

Rusman. Belajar dan Pembelajaran Berorientasi Standar Proses Pendidikan. Jakarta: Kencana, 2017.

Sareong, Irene Priskila dan Tri Supartini. "Hubungan Komunikasi Interpersonal Guru dan Siswa Terhadap Keaktifan Belajar Siswa di SMA Kristen Pelita Kasih Makassar."

Jurnal Ilmu Teologi dan Pendidikan Agama Kristen 1, no. 1 (Juni 2020): 29-42. https://ojs.sttjaffray.ac.id/jitpk/article/view/466/pdf_2.

Satrianawati. Media Dan Sumber Belajar. Yogyakarta: Penerbit Deepublish, 2018.

Serli dan Hengki Wijaya. "Metode Permainan Dalam Meningkatkan Pemahaman Firman

Tuhan Pada Remaja GKII Okahapi Sumba Timur.” Jurnal Ilmu Teologi dan

Pendidikan Agama Kristen 1, no. 1 (Juni 2020): 17-28.

https://ojs.sttjaffray.ac.id/jitpk/article/view/459/pdf_1.

Setiawan, Andi. Belajar dan Pembelajaran. Sidoharjo: Uwais Inspirasi Indonesi, 2002.

Kementrian Komunikasi dan Informatika Republik Indonesia, "Jumlah Pengguna Telekomunikasi Seluler Prabayar Hasil Rekonsiliasi dan Berakhirnya Program Registrasi Ulang." SIARAN PERS NO. 112/HM/KOMINFO/05/2018. Diakses 20 
Maret 2019. https://kominfo.go.id/index.php/ content/detail /13125/siaran-pers-no112hmkominfo052018-tentang-jumlah-pelanggan- telekomunikasi-seluler-prabayarhasil-rekonsiliasi-dan-berakhirnya-program-registrasi-ulang/0/siaran_pers.

Susanto, Dedy. "Penggunaan Smartphone Dan Locus of Control: Keterkaitannya Dengan Prestasi Belajar, Kualitas Tidur, Dan Subjective Well-Being." Jurnal Psikologi Sosial 16, No. 2 (2018): 125-138.

http://journal.ui.ac.id/index.php/jps/article/view/jps.2018.12.

Sulastri, Yuyu Laila dan Luki Liqmanul Hakim. "Belajar Berbasis Mobile." Jurnal Pengajaran MIPA 19, No. 2 (2013): 173-178. http://journal.fpmipa.upi.edu/index.php/jpmipa/article/view/458.

Sukrillah, Ratnamulyani dan Kusumadinata. "Manfaat Media Sosial Melalui WhatsApp Group FEI Sebagai Saran Komunikasi." Jurnal Komunikatio 3, No. 2 (2018): 59104.

https://www.researchgate.net/publication/324629426_PEMANFAATAN_MEDIA_S OSIAL_MELALUI_WHATSAPP_GROUP_FEI_SEBAGAI_SARANA_KOMUNI KASI.

Suparno, Paul. Teori Perkembangan Kognitif Jean Piaget. Yogyakarta: Penerbit Kanisius, 2006.

Sumantri, Mohamad Syarif. Strategi Pembelajaran. Jakarta: RajaGrafindo Persada, 2016.

Suparadi, Yuniar. Optimlisasi HP dan SimCard Pribadi. Jakarta: Elex Media Komputindo, 2011.

Tim Redaksi. "Youtube, Medsos No.1 Di Indonesia." Dkatadata.co.id, Kamis, 23 Mei 2019. https://katadata.co.id/infografik/2019/03/06/youtube-medsos-no-1-diindonesia.

Timbowo, Deify. "Manfaat Penggunaan Smartphone Sebagai Media Komunikasi," EJurnal Acta Diurna 5, No. 2 (2016): 1-13.

https://ejournal.unsrat.ac.id/index.php/actadiurna/article/view/11719.

Tolle, Herman. Aryo Pinandito, Agi Putra, Kharisma, Ratih Kartika Dewi. Pengembangan Aplikasi Perangkat Bergerak. Malang: UB Press, 2017.

TV, Saddha. "Youtube." 12 April 2018. https://www.youtube.com/watch?v=_8UNhgvSY2A.

Trivena, Intan. Maria Daeng N.N Mewengkang Edmon R Kalesaran. "Penggunaan Smartphone Dalam Menunjang Aktivitas Perkuliahan Oleh Mahasiswa Fispol Unsrat Manado." Jurnal ACTA DIURNA 8. 2017. https://ejournal.unsrat.ac.id/index.php/actadiurna/article/view/15482/15023.

Ukisnawati, Alufi Eka. Demam Gadget (Smartphone) Dalam Visualisasi Jati Diri Mahasiswa," Skripsi, S.Ant, Gadjah Mada University 7, no. 3 (2014): 1-15. http://proceeding.unisba.ac.id/index.php/sosial/article/view/1287/pdf.

Unaradjan, Dominikus Dolet. Metode Penelitian Kuantitatif. Jakarta: Penerbit Universitas Katolik Indonesia Atma Jaya, 2019.

Visi dan Misi Kampus. 16 Juni 2019. https://www.sttjaffray.ac.id/profil/visi-dan-misi.

Warsita, Bambang. Teknologi Pembelajaran: Landasan Dan Aplikasinya. Jakarta: Rineka Cipta, 2008. Diikuti oleh Andi Prastowo, Sumber Belajar \& Pusat Pembelajaran. Depok: Prenadamedia Group, 2018.

Yaumi, Muhammad. Media dan Teknologi Pembelajaran. Jakarta: Prenadamedia Group, 2018.

Yuniati, Yenni dan Teguh Ratmanto. "Smartphone Sebagai Media Pembelajaran.” Student Centered Learning 7 (2017): 751-764.

http://proceeding.unisba.ac.id/index.php/sosial/article/view/1287/pdf. 
